Jackson, H.M. Astronomer, Cape of Good Hope; Prof. T. J. Jenkin, director of the Welsh Plant Breeding Station, Aberystwyth; Major-General S. W. Joslin, late of the Corps of Royal Electrical and Mechanical Engineers; Dr. Harold King, formerly head of the Chemistry Division, National Institute for Medical Research; Mr. W. B. Mercer, provincial director, National Agricultural Advisory Service; Dr. J. R. K. Paterson, director of the Holt Radium Institute, Manchester; Capt. C. R. S. Pitman, formerly game warden, Uganda; Capt. J. L. Pritchard, secretary of the Royal Aeronautical Society ; Mr. A. G. Ramsey, chief mechanical and electrical engineer, Ministry of Works; Mr. T. Rowntree, director of aeronautical inspection, Ministry of Supply; Mr. C. A. Spencer, deputy chief scientific officer, Department of Scientific and Industrial Research; Prof. O. G. Sutton, professor of mathematical physics, Military College of Science; Prof. H. H. Swinnerton, emeritus professor of geology in the University of Nottingham, and chairman of the University of Nottingham Joint Recruiting Board ; Dr. A. J. Turner, director of research, Linen Industry Research Association; Colonel B. Ungerson, late of the Royal Army Educational Corps; Mr. G. M. Wright, engineer-in-chief, Marconi's Wireless Telegraph Co.

I.S.O.: Mr. L. S. Davis, Government chemist, Trinidad; Mr. C. A. Leembruggen, formerly assistant director of surveys, Fiji ; Mr. G. H. Makey, principal examiner, Patent Office and Industrial Property Department, Board of Trade; Capt. A. E. W. Nesbitt, surveyor, Gold Coast.

\section{Inorganic and Physical Chemistry at Leeds:}

Dr. F. S. Dainton

Dr. F. S. ('Fred') Darnton, at present H. O. Jones lecturer in physical chemistry in the University of Cambridge, has recently been appointed to the vacant chair of inorganic and physical chemistry in the University of Leeds. There are two such chairs at Leeds, and the other one is already occupied by Prof. E. G. Cox. Dr. Dainton was educated in the local primary and grammar schools in Sheffield and in 1933 entered St. John's College, Oxford, as an open exhibitioner, where he studied under Dr. H. W. Thompson. After taking a first-class honours schools (chemistry) in 1937, he went to Cambridge with a Goldsmiths' Company studentship and support from Imperial Chemical Industries, Ltd., and worked in collaboration with Prof. R. G. W. Norrish on reaction kinetics. Their work on the sensitized ignition of hydrogen oxidation largely established the importance of the thermal factor in the passage of a degenerate chain reaction to ignition. Subsequent to receiving his Ph.D. degree in 1940, Dr. Dainton was engaged in teaching and in war research at Cambridge with the Ministry of Supply. In 1945 he was elected a fellow of St. Catharine's College and in 1946 appointed Humphrey Owen Jones lecturer in the Department of Physical Chemistry, Cambridge. Dr. Dainton's later work, carried out in collaboration with his research students, has established him as an authority in the field of reaction kinetics. Special mention may be made of recent studies of the effects of ionizingradiation on water, in which, by applying a variety of physico-chemical techniques, the production of hydrogen atoms and hydroxyl radicals has been demonstrated and their effects on various reaction processes, including polymerization, described. In his translation to Leeds, Dr. Dainton is returning to his home ground; his many friends in Cambridge will wish him every success, but he will be much missed in more than one quarter.

\section{Fiftieth Anniversary of the Discovery of the Grignard Reagents}

ThE fiftieth anniversary of the discovery of the Grignard reagents by Victor Grignard was celebrated at the University of Lyons on May 13. The celebrations were organised in collaboration with the Société Chimique de France, Industries Chimiques de la Région Lyonnaise, Association des Anciens Élèves de l'École de Chimie Industrielle de Lyon, and the Fondation Scientifique de Lyon et du Sud-Est. The morning session opened with an introduction by the rector of the University, M. André Allix, and this was followed by an oration on the origin, development and significance of the Grignard reagents, which was delivered by Prof. R. Locquin, correspondant of the Paris Academy of Sciences. 'Then 'vin d'honneur' and a lunch were given by the Rector and Council of the University of Lyons to a gathering which included Mm9. Grignard and other members of the late Prof. Grignard's family, and representatives from many universities and institutions in France and elsewhere. The Chemical Society (Great Britain) was represented by Prof. D. H. Hey and Prof. H. Burton, honorary secretaries. In the afternoon a commemorative plaque was unveiled in the entrance hall of the Chemical Institute of the University of Lyons by the granddaughter of Prof. Grignard. At the concluding ceremony, held at the University, addresses were read by Prof. G. Dupont (director of the École Normale Supérieure and professor of theoretical chemistry in the Sorbonne), Prof. Ch. Dufraisse (professor of organic chemistry in the College de France), Prof. D. H. Hey and Prof. P. Karrer (rector of the University of Zurich), in which tribute was paid to the memory of this distinguished French chemist.

\section{Public Health Engineering Course in London}

MaNY American universities have flourishing schools of public health engineering, some at undergraduate level, but mostly postgraduate. In Great Britain the subject as one for university study has been very badly neglected, in spite of its importance both at home and in the Colonial Empire. The International Health Division of the Rockefeller Foundation, as part of its programme for raising the standard of public health throughout the world, has generously provided funds to enable the Imperial College of Science and Technology, London, in co-operation with the London School of Hygiene and Tropical Medicine, to inaugurate a full-time postgraduate course in this subject, beginning in October next. The syllabus is designed on broad lines, and is intended to cater both for those engineers who will take up municipal or consulting work in Great Britain and for those who will be concerned with development in the Colonies or in other parts of the world. The subjects to be covered at the Imperial College will include the principles of public health engineering, water supply and treatment, sewerage and sewage treatment, statistics, bacteriology and applied entomology. The London School of Hygiene will give courses on public health and local government, epidemiology, occupational health and tropical hygiene. A feature of the course to which much importance is attached is that in a number of classes engineers and medical men who are studying public 